\title{
Iron, lactoferrin and iron regulatory protein activity in the synovium; relative importance of iron loading and the inflammatory response
}

\author{
C Guillén, I B McInnes, H Kruger, J H Brock
}

\begin{abstract}
Objectives-To determine the ability of lactoferrin in rheumatoid arthritis (RA) synovial fluid to bind "free" iron, and to study the regulatory mechanisms therein that control iron homeostasis.

Methods-"Free" iron was determined by the bleomycin assay and lactoferrin concentrations by enzyme linked immunosorbent assay. The activities of iron regulatory protein (IRP) and $N F-\kappa B$ in synovial fluid cells were assayed by mobility shift assay.

Results-30\% of synovial fluids contained "free" iron and in these, lactoferrin concentrations were significantly lower than in those with no "free" iron $(p<0.01)$. Addition of exogenous lactoferrin consistently reduced the amount of "free" iron in positive synovial fluids. IRP activity in synovial cells did not correlate with synovial fluid iron concentrations but did correlate with $\mathrm{NF}-\kappa \mathrm{B}$ activation and with serum $C$ reactive protein.

Conclusion-Lactoferrin may prevent iron mediated tissue damage in RA by reducing "free" synovial iron concentration when inflammatory stimuli have disregulated IRP mediated iron homeostasis. (Ann Rheum Dis 1998;57:309-314)
\end{abstract}

In inflammatory disease iron homeostasis is disturbed, resulting in accumulation of iron in the liver, spleen, and at local sites of inflammation, while iron supply to the marrow is reduced, giving rise to the anaemia of chronic disease. In rheumatoid arthritis (RA) iron accumulates in the synovial membrane, particularly in macrophages, and at high concentrations in synovial fluid. ${ }^{1}$ The amount of iron in the synovial fluid enviroment may exceed the capacity of iron binding proteins and resulting "free" iron can then catalyse the production of hydroxyl radicals $(\mathrm{OH} \bullet)$ from superoxide $\left(\mathrm{O}_{2}^{-}\right)$and hydrogen peroxide $\left(\mathrm{H}_{2} \mathrm{O}_{2}\right)$ (ROI). $\mathrm{OH} \bullet$ can in turn cause membrane damage, hyaluronic acid degradation, inactivation of proteinase inhibitors, and destruction of several antioxidants within the synovial membrane. ${ }^{2}$

Cellular iron homeostasis is largely controlled post-transcriptionally in the cytoplasm. A cis-acting RNA motif, the iron responsive element (IRE), and trans-acting cytoplasmic proteins, known as iron regulatory proteins (IRPs) coordinate iron dependent expression of the intracellular storage protein ferritin, the transferrin receptor, which is critical for cellu- lar uptake of iron, and of erythroid 5-amino laevulinic acid synthase (e-ALAS), the first enzyme of the haem biosynthetic pathway. Iron deprivation stimulates IRP binding to the IRE, thereby repressing ferritin and e-ALAS mRNA translation and protecting transferrin receptor mRNA from degradation. ${ }^{34}$ This results in increased transferrin receptor expression and hence iron uptake. Inflammatory mediators such as $\mathrm{NO}$ and $\mathrm{H}_{2} \mathrm{O}_{2}$ can stimulate the IRE binding activity of $\operatorname{IRP}^{5}$ and these may therefore disrupt the normal iron regulated activity of IRP. Alteration of IRP function in the rheumatoid joint might therefore contribute to the local accumulation of iron in the joint. This possibility has not previously been investigated.

Inflammatory mediators, including cytokines (IL1 $\beta, T N F \alpha$ ) and ROI, also activate the transcription factor $\mathrm{NF}-\kappa \mathrm{B}$, a heterodimeric DNA binding protein that induces the expression of multiple genes implicated in synovial inflammation. ${ }^{6}$ In non-stimulated cells, NF- $\mathrm{BB}$ exists in an inactive, cytosolic form, bound to an inhibitor, IкB. Upon stimulation, $\mathrm{I} \kappa \mathrm{B}$ dissociates from the complex and is degraded leaving the active dimeric form of $\mathrm{NF}-\kappa \mathrm{B}$, which is translocated to the nucleus, where it regulates gene expression. As $\mathrm{H}_{2} \mathrm{O}_{2}$ seems to be involved in activation of both $\mathrm{NF}-\kappa \mathrm{B}$ and IRP, it is likely that NF- $\mathrm{BB}$ activation will parallel that of IRP in response to inflammatory stimuli in diseases such as RA although this has not yet been described.

In view of the pro-inflammatory effect of "free" iron in the synovium, enhancement of levels of iron binding proteins within the synovium that could sequester "free" iron offers attractive therapeutic potential. Lactoferrin, an iron binding protein of external secretions and neutrophil granules, would be particularly effective in this respect as it has high affinity for iron, even at $\mathrm{pH}$ values as low as $4.0 .^{7}$ Unlike transferrin, lactoferrin could maintain iron binding at $\mathrm{pH} 5-6$, such as is found in the inflammed synovial microenviroment. ${ }^{8}$ The role of lactoferrin in binding iron in the synovium has not previously been investigated.

In this study, we have examined the relation between iron and lactoferrin concentrations in synovial fluids and have investigated the relative ability of lactoferrin and transferrin to bind "free" iron in synovial fluid. In addition, to further understand iron accumulation in the RA synovium we have examined the activity of IRP and compared it with NFKB in cells from 
Table 1 Characteristics of patients selected for study

\begin{tabular}{|c|c|c|c|c|c|c|c|c|}
\hline Patient & $\begin{array}{l}\text { Age } \\
(y)\end{array}$ & Disease & $\begin{array}{l}\text { Duration } \\
\text { (y) }\end{array}$ & $\begin{array}{l}\text { Rheumatoid } \\
\text { factor }\end{array}$ & $\begin{array}{l}\text { ESR } \\
\text { (mm } \\
1 \text { st h) }\end{array}$ & $\begin{array}{l}C R P \\
(m g / l)\end{array}$ & $\begin{array}{l}H b \\
(g / d l)\end{array}$ & $\begin{array}{l}M C V \\
(f)\end{array}$ \\
\hline 1 & 47 & RA & 8 & + & 30 & 52 & 10.0 & 71.0 \\
\hline 2 & 61 & RA & 20 & + & 66 & 8 & 9.5 & 92.0 \\
\hline 3 & 64 & RA & N/A & N/A & 97 & 32 & 11.0 & 90.0 \\
\hline 4 & 26 & RA & 9 & + & 97 & 32 & 11.0 & 97.0 \\
\hline 5 & 89 & RA & 20 & + & 65 & 89 & 9.3 & 81.0 \\
\hline 6 & 48 & RA & 5 & - & N/A & $<6$ & N/A & N/A \\
\hline 7 & 69 & RA & 16 & + & 27 & $<6$ & 11.7 & 86.0 \\
\hline 8 & 44 & RA & 16 & - & 46 & 23 & 11.9 & 80.0 \\
\hline 9 & 47 & RA & 8 & + & 30 & 52 & 10.0 & 71.0 \\
\hline 10 & 78 & RA & 8 & + & 26 & 44 & 12.4 & 82.0 \\
\hline 11 & 74 & RA & 16 & + & N/A & 8 & 12.2 & N/A \\
\hline 12 & 57 & RA & 5 & + & 43 & 49 & 11.7 & 85.0 \\
\hline 13 & 59 & RA & N/A & N/A & 10 & $<6$ & 14.5 & 89.4 \\
\hline 14 & 71 & RA & N/A & N/A & 43 & 15 & 12.0 & 94.1 \\
\hline 15 & 63 & RA & 16 & + & 78 & 91 & 10.0 & 85.0 \\
\hline 16 & 69 & RA & N/A & N/A & 44 & 25 & 12.1 & 97.0 \\
\hline 17 & 65 & RA & 18 & - & 23 & 29 & 13.2 & 81.0 \\
\hline 18 & 67 & RA & N/A & N/A & 41 & N/A & 13.6 & 108.0 \\
\hline 19 & 74 & RA & 16 & + & N/A & 8 & 12.2 & N/A \\
\hline 20 & 69 & RA & 21 & + & N/A & 76 & 10.6 & N/A \\
\hline 21 & 34 & RA & 7 & + & N/A & 87 & 14.1 & N/A \\
\hline 22 & 75 & RA & 40 & + & N/A & 8 & 12 & N/A \\
\hline 23 & 19 & JCA & 5 & - & 22 & 38 & 11.5 & 84.0 \\
\hline 24 & 22 & JCA & 7 & + & 68 & 75 & 10.0 & 75.0 \\
\hline 25 & 41 & PSO & 3 & - & 51 & 40 & 12.3 & 87.0 \\
\hline
\end{tabular}

RA = rheumatoid arthritis; JCA = juvenile chronic arthritis; $\mathrm{PSO}=$ psoriasis; N/A = data not available.

synovial fluid, to determine whether there is a correlation between the activation of these critical regulatory proteins.

\section{Methods}

PATIENTS

Twenty five patients with inflammatory synovitis were studied (22 rheumatoid arthritis, two juvenile rheumatoid arthritis, and one psoriatic arthritis) (20 women and five men, age range 19-89) (table 1). ACR classification criteria were achieved as appropiate..$^{9-11}$ Not all patients were included in each analysis. All subjects gave their informed consent.

\section{REAGENTS}

Human iron free (apo) lactoferrin was obtained from Sigma (Poole, UK), mouse apolactoferrin was a gift from Dr Günter Sawatzki (Milupa, Friedrichshafen, Germany), and

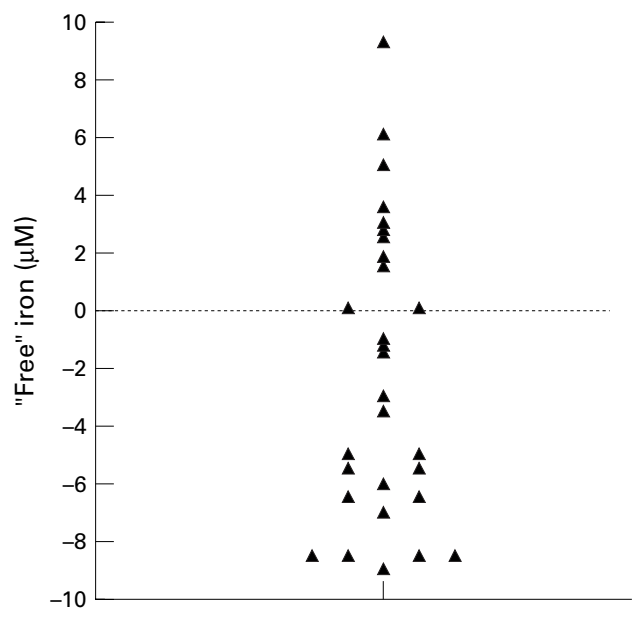

RA synovial fluid samples

Figure 1 "Free" iron in synovial fluid of $R A$ patients. The results represent the concentrations of "free" iron in $R A$ patients using the bleomycin assay at $\mathrm{pH}$ 5.3. apotransferrin was obtained from Behringwerke (Hounslow, Middx, UK).

CELL SEPARATION AND SAMPLE PREPARATION Synovial fluid samples were obtained during routine diagnostic or therapeutic aspiration. Samples showing evidence of contamination by blood were discarded. Mononuclear cells were isolated by Ficoll-Hypaque (Lymphoprep, Nyegaard, Oslo, Norway) density gradient centrifugation. Total synovial fluid cells were obtained by centrifugation of the fluid at $1800 \mathrm{~g}$ for five minutes. The supernatant was aspirated and stored at $-20^{\circ} \mathrm{C}$ for use in the bleomycin assay for "free" iron. Separation of cells from fluid was always performed within one hour of aspiration.

For determination of IRP and NFאB activity in the same cell sample a combined cytoplasmic and nuclear protein extraction method was developed as follows. The cell pellet was resuspended in $500 \mu \mathrm{l}$ of cytoplasmic lysis buffer $(10$ mM HEPES ( $\mathrm{pH} 7.9$ ), $1.5 \mathrm{mM} \mathrm{MgCl}, 10 \mathrm{mM}$ $\mathrm{KCl}, 0.5 \mathrm{mM}$ dithiothreitol (DTT), $0.2 \mathrm{mM}$ phenylmethylsulphonyl fluoride (PMSF), 0.1 mM EDTA, $0.1 \mathrm{mM}$ 1,2-D (2 aminoethoxy) ethane-N,N,N',N'-tetra-acetic acid (EGTA), $50 \mu \mathrm{g} / \mathrm{ml}$ leupeptin, $1 \mathrm{mM}$ benzamidine, 50 $\mu \mathrm{g} / \mathrm{ml}$ pepstatin A) with gentle pipetting and left on ice for 15 minutes. To this $25 \mu$ of a $10 \%$ solution of NP-40 were added, the tube vortexed vigorously for 15 seconds, and then centrifuged at $13000 \mathrm{rpm}$ for one minute. The supernatant from this step contained the cytoplasmic protein and was stored in aliquots at $-70^{\circ} \mathrm{C}$ for determination of IRP activity. To the pellet $100 \mu \mathrm{l}$ of ice cold nuclear lysis buffer $(20$ mM HEPES (pH 7.9), 25\% glycerol, $420 \mathrm{mM}$ $\mathrm{NaCl}, 1.5 \mathrm{mM} \mathrm{MgCl}, 1 \mathrm{mM}$ EDTA, $1 \mathrm{mM}$ DTT, $1 \mathrm{mM}$ PMSF, $50 \mu \mathrm{g} / \mathrm{ml}$ leupeptin, $1 \mathrm{mM}$ benzamidine, $50 \mu \mathrm{g} / \mathrm{ml}$ pepstatin A) was added and the tube was vigorously rocked at $4^{\circ} \mathrm{C}$ for 20-30 minutes, and then centrifuged at 13000 $\mathrm{rpm}$ for 10 minutes at $4^{\circ} \mathrm{C}$. The resulting supernatant contained the nuclear protein and was stored in aliquots at $-70^{\circ} \mathrm{C}$ for determination of $\mathrm{NF} \kappa \mathrm{B}$ activation.

DETERMINATION OF "FREE" IRON

A modification of the bleomycin assay of Gutteridge $e t a l^{12}$ was used. Briefly, $0.5 \mathrm{ml}$ of 1 $\mathrm{mg} / \mathrm{ml} \mathrm{DNA} \mathrm{(Sigma,} \mathrm{Poole,} \mathrm{UK),} 0.05 \mathrm{ml}$ of $1.5 \mathrm{U} / \mathrm{ml}$ bleomycin sulphate (Sigma, Poole, $\mathrm{UK}), 0.1 \mathrm{ml}$ of $50 \mathrm{mM} \mathrm{MgCl}, 0.1 \mathrm{ml}$ of buffer (either $1 \mathrm{M}$ sodium phosphate $\mathrm{pH} 7.4$ or $1 \mathrm{M}$ sodium acetate $\mathrm{pH} 5.3), 0.05 \mathrm{ml}$ of sample and $0.1 \mathrm{ml}$ of ascorbic acid $(1.4 \mathrm{mg} / \mathrm{ml})$ were added in the order stated and incubated at $37^{\circ} \mathrm{C}$ for one hour with shaking. After incubation, $0.1 \mathrm{ml}$ of $0.1 \mathrm{M}$ EDTA was added, followed by $0.5 \mathrm{ml}$ of thiobarbituric acid $(1 \% \mathrm{w} / \mathrm{v}$ in $50 \mathrm{mM}$ $\mathrm{NaOH}$ ) and $0.5 \mathrm{ml}$ of $3 \mathrm{M} \mathrm{HCl}$. Solutions were heated at $80^{\circ} \mathrm{C}$ for 20 minutes, cooled, and the chromogen extracted into $1 \mathrm{ml}$ of butan-1-ol and asssayed spectrophotometrically at 532 $\mathrm{nm}$. To minimise contamination with exogenous iron, all reagents except bleomycin were incubated overnight with Chelex 100 iron exchange resin (Sigma) before use. 

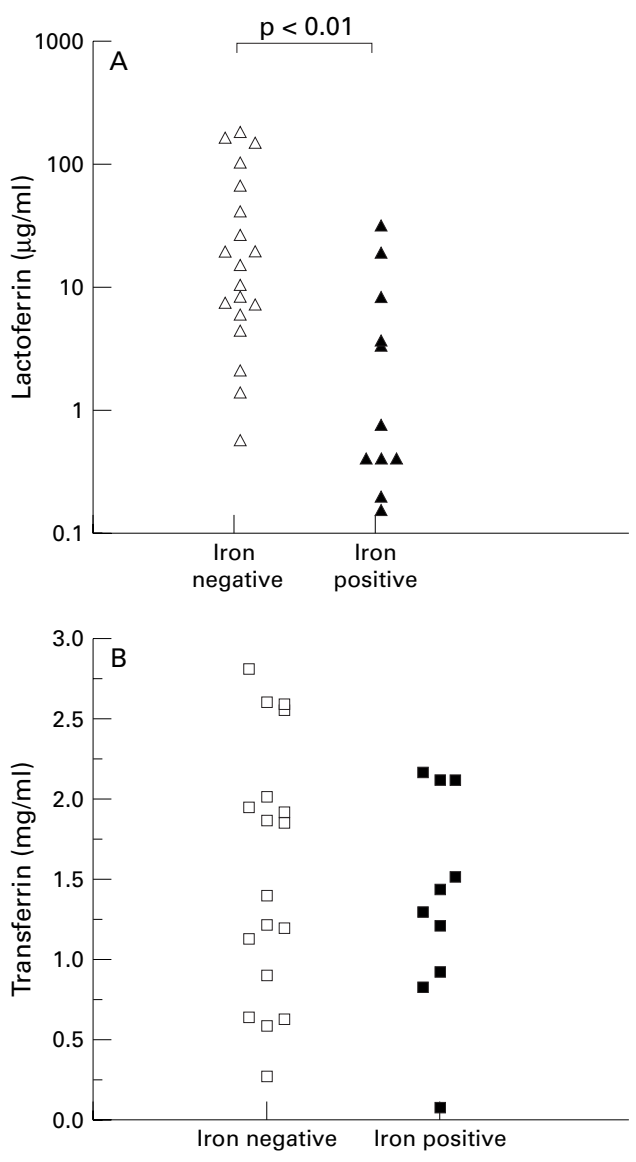

Figure 2 Lactoferrin $(A)$ and transferrin $(B)$ in synovial fluid from $R A$ patients. The results correspond to the synovial fluid lactoferrin and transferrin concentrations in $R A$ patients segregated for the presence or absence of "free" iron. Lactoferrin concentrations were significantly lower $(p<0.01)$ in fluids containing "free" iron. There was no significant difference in transferrin concentrations.

IRP AND NFKB ACTIVITY

IRP activity was determined by mobility shift assay, using a ${ }^{32} \mathrm{P}$-labelled oligoribonucleotide probe containing the ferritin IRE sequence ${ }^{13}$ obtained by in vitro transcription of an

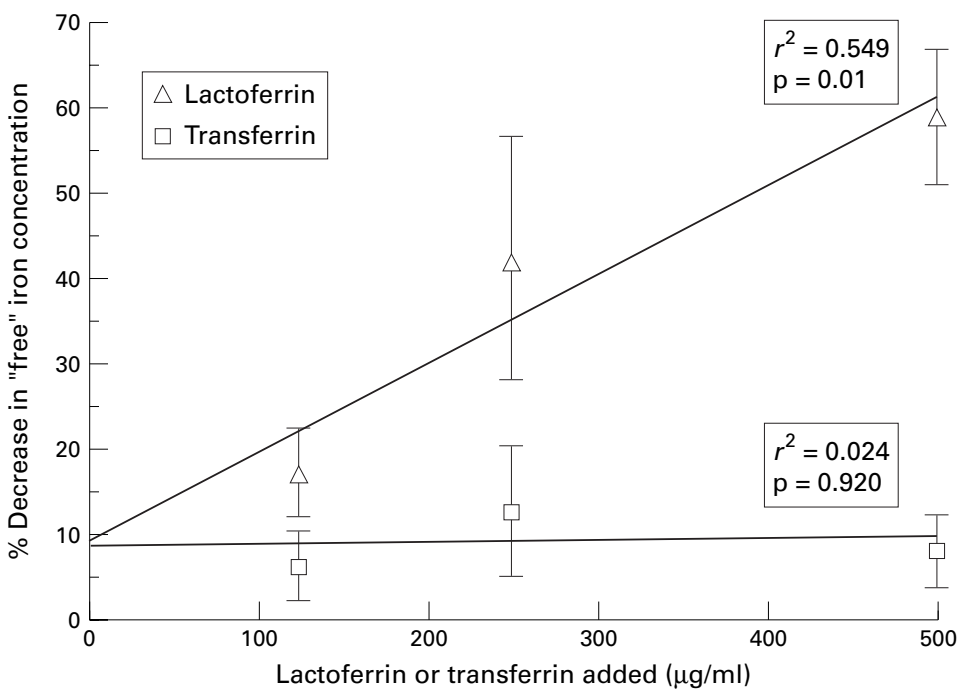

Figure 3 Binding of iron in synovial fluid by exogenous lactoferrin and transferrin. Synovial fluid samples were incubated overnight at $4^{\circ} \mathrm{C}$ with different concentrations of lactoferrin or transferrin and "free" iron was measured by the bleomycin assay. The results show the percentage decrease in "free" iron (mean $(S E M) ; n=7)$ for each concentration of exogenous lactoferrin or transferrin.
IRE-CAT plasmid (kindly provided by Dr N Gray, EMBL, Heidelberg) linearised with $X b a I$. Total IRP was determined by incubating samples with 2 -mercaptoethanol $(2 \%)$ for 10 minutes before assay, which converts inactive IRP to the RNA binding form. ${ }^{14}$ Omission of 2-mercaptoethanol allowed only the spontaneously active IRP to be assayed. The relative intensities of bands corresponding to IRE-IRP complexes in samples with or without 2- mercaptoethanol were quantified by densitometry and the proportion of spontaneously active IRP calculated. Approximately $70 \mu \mathrm{g}$ of cytoplasmic protein was loaded per sample. NFKB activity was determined by mobility shift assay using a ${ }^{32} \mathrm{P}$-labelled oligonucleotide probe (5'-CCCAACTGGGGACTCTCCCTTTGG) containing the $\mathrm{NF} \kappa \mathrm{B}$ site sequence found in the inducible nitric oxide synthase (iNOS) promoter (kindly provided by Dr X Wei, Department of Immunology, Glasgow University). Approximately $5 \mu \mathrm{g}$ of nuclear protein was loaded per sample.

BINDING OF SYNOVIAL FLUID IRON BY

LACTOFERRIN AND TRANSFERRIN

Synovial fluids known to contain "free" iron were incubated overnight at $4^{\circ} \mathrm{C}$ with various concentrations of human lactoferrin or transferrin, and "free" iron levels were then determined by the bleomycin assay.

LACTOFERRIN, TRANSFERRIN, AND ALBUMIN IN SYNOVIAL FLUID

Lactoferrin and transferrin were determined by a sandwich ELISA. For lactoferrin, a polyclonal anti-lactoferrin rabbit antiserum was raised and the IgG fraction used for coating, followed by addition of samples or standards. The rabbit anti-lactoferrin IgG was coupled to alkaline phosphatase and used as second antibody, and the assay developed with $p$-nitrophenyl phosphate. The minimum concentration of lactoferrin that could be measured by this assay was $350 \mathrm{ng} / \mathrm{ml}$. For transferrin, the IgG fraction of a sheep anti-transferrin antiserum (SAPU, Lanark, UK) was used for coating. An unlabelled rabbit anti-transferrin antiserum was used as second antibody, and a horseradish peroxidase coupled donkey anti-rabbit IgG (SAPU) used for development. Albumin was determined using radial immunodiffusion plates (Behringwerke, Marburg, Germany).

\section{STATISTICAL ANALYSIS}

Data were analysed using Pearson's correlation or Student's $t$ test as appropriate. A p value of $<0.05$ was considered to indicate a significant difference between groups.

\section{Results}

"FREE" IRON IN SYNOVIAL FLUID OF RA PATIENTS The presence of "free" iron in synovial fluids of RA patients was determined by the bleomycin assay. When the assay was performed at $\mathrm{pH}$ 7.4 , none of the fluids demonstrated unbound iron (data not shown) as previously reported by Gutteridge. ${ }^{15}$ In contrast, at $\mathrm{pH} 5.3$, which represents the microenviroment surrounding cells, such as activated macrophages, which produce 

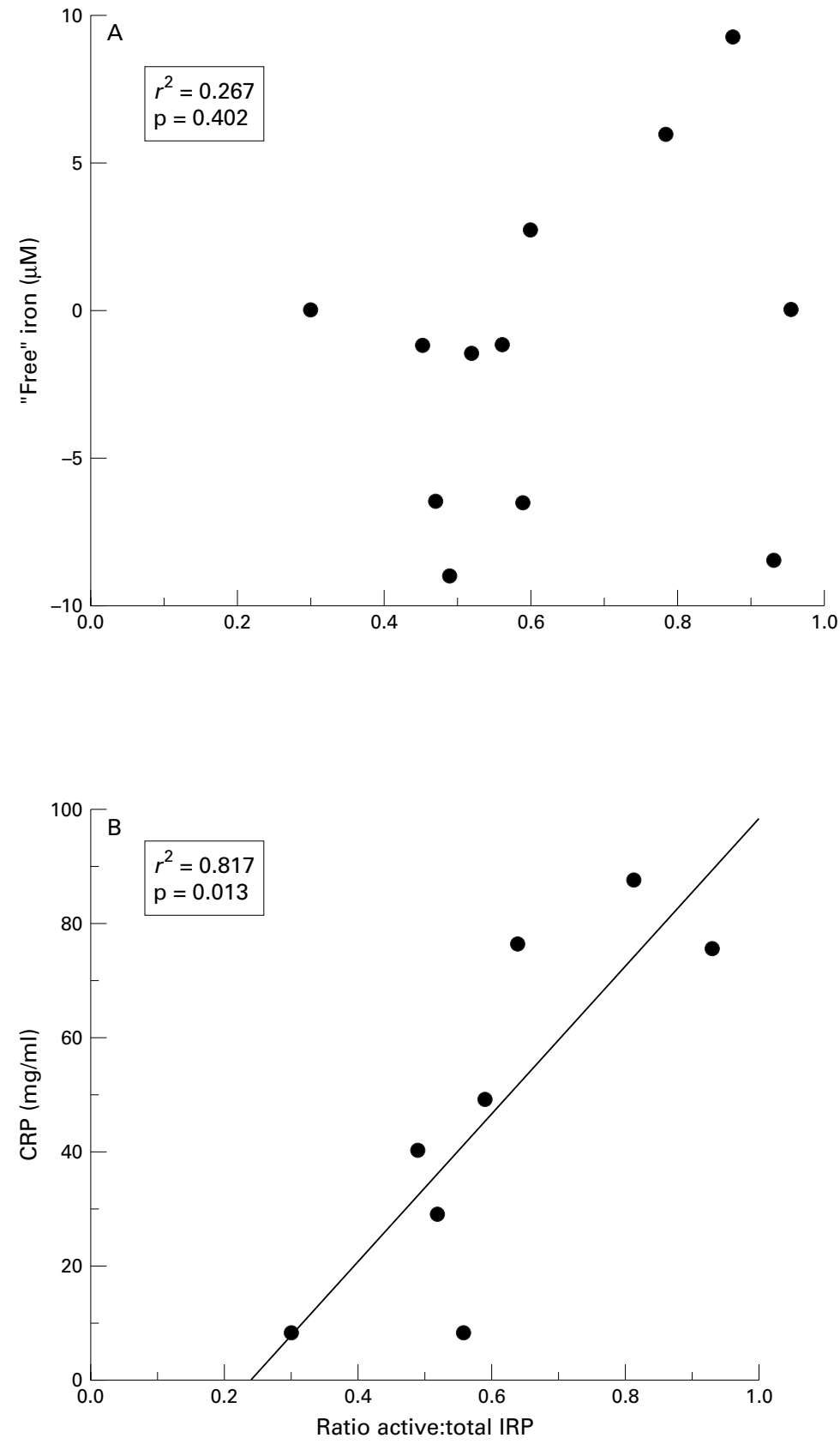

Figure 4 Correlation between iron regulatory protein (IRP) activity in synovial fluid cells of $R A$ patients with "free" iron $(A)$ and CRP $(B)$. IRP activity was calculated from the ratio of intensity of IRE-IRP complexes in mobility shift assays performed with or without 2-mercaptoethanol. Serum CRP concentrations correlated with IRP activity $(p=0.013)$

ROI, nine of 30 samples analysed contained "free" iron, the maximum concentration being $10 \mu \mathrm{M}$ (fig 1). The rest except two gave "negative" values. This can be estimated because in this assay the blank is always high because of contaminating iron in reagents. Iron binding proteins can bind contaminating iron in the reagents, giving readings lower than the blank. ${ }^{16}$ There was no significant correlation between "free" iron/iron binding capacity and any of the clinical parameters shown in table 1 .

NEGATIVE CORRELATION BETWEEN LACTOFERRIN AND "FREE" IRON IN SYNOVIAL FLUID FROM RA PATIENTS

Synovial fluid lactoferrin and transferrin were measured by ELISA and compared in the

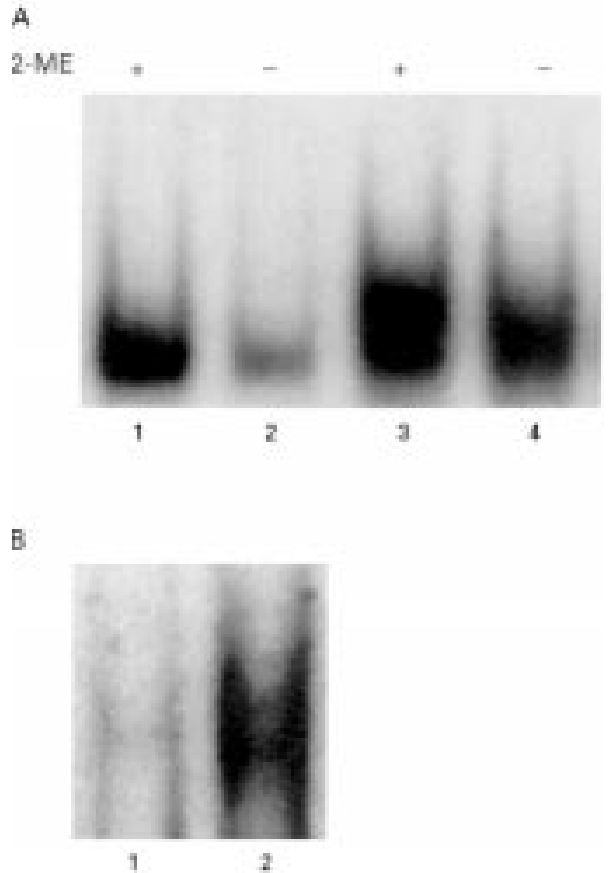

Figure 5 Mobility shift assay of IRP $(A)$ and $N F \kappa B(B)$ from synovial fluid mononuclear and polymorphonuclear cells from a representative case of three RA patients. In panel $A$, lanes 1 and 2 correspond to active IRP in synovial fluid mononuclear cells and lanes 3 and 4 to active IRP in synovial fluid polymorphonuclear cells. Samples in lanes 1 and 3 were treated with 2-mercaptoethanol (2-ME) to convert inactive IRP to the active form (see methods). In panel $B$, lane 1 corresponds to $N F \kappa B$ activity in synovial fluid mononuclear cells and lane 2 to NFKB activity in synovial fluid polymorphonuclear cells.

context of positive or negative iron detection (fig 2). Synovial fluids from RA patients with "free" iron contained significantly less lactoferrin than these without $(p<0.01)$, but there was no difference in transferrin concentration. The mean overall lactoferrin concentration (28.5 $\mu \mathrm{g} / \mathrm{ml}$ ) was always much lower than the mean transferrin concentration $(1.54 \mathrm{mg} / \mathrm{ml})$. However, serum lactoferrin concentrations are much lower $(\leqslant 1 \mu \mathrm{g} / \mathrm{ml}),{ }^{17}$ whereas the ratio of transferrin to albumin in synovial fluid (0.048) was found to be only slightly below the normal serum ratio $(0.065)$, indicating that transferrin probably enters the synovium by simple transudation.

BINDING OF "FREE" IRON IN SYNOVIAL FLUID BY LACTOFERRIN AND TRANSFERRIN

To study whether exogenous lactoferrin and transferrin could bind "free" iron in synovial fluid, seven RA synovial fluids, known to contain "free" iron were incubated overnight with lactoferrin or transferrin. Human lactoferrin neutralised "free" iron in synovial fluid in a dose dependent manner $(p=0.01)$, while transferrin had no effect ( $p>0.05$ ) (fig 3 ).

\section{IRP ACTIVITY CORRELATES WITH THE ACUTE} PHASE REACTANT, CRP

To determine whether up regulation of IRP activity might contribute to iron accumulation in the synovium, total and active IRP was determined in cells isolated from the synovial fluid of 14 RA patients. The ratio of active to 
total IRP was then calculated. Active IRP was present in synovial fluid cells, but did not correlate with "free" iron concentrations (fig 4A). However, there was a significant positive correlation ( $r=0.817, \mathrm{p}=0.013)$ between IRP activity and serum CRP (fig 4B).

INCREASE IN IRP ACTIVITY CORRELATES WITH NFKB ACTIVATION AND DEPENDS ON THE TYPE OF CELL AND THE ORIGIN

As IRP activity correlated with CRP, a parameter of inflammation, but not with synovial iron concentrations, the possible correlation between IRP activity and activation of $\mathrm{NF} \kappa \mathrm{B}$ was investigated. For this study mononuclear and polymorphonuclear cells were isolated from synovial fluid, and each population examined for IRP and NFKB activity by mobility shift. A study of three patients showed that cell populations showing high IRP activity invariably showed the highest degree of NFKB activation. A typical result is shown in figure 5, in which the synovial mononuclear cells show low IRP activity (frame A, compare lane 2 with lane 1) and low NFKB activity (frame B, lane 1 ), where the polymorphonuclear cells from the same patient show high IRP activity (frame A, compare lane 4 with lane 3 ) and high $N F \kappa B$ activity (frame $\mathrm{B}$, lane 2).

\section{Discussion}

Accumulation of iron in the synovium of RA patients is thought to contribute towards tissue damage. ${ }^{1}$ Iron chelation or deprivation can reduce joint inflammation in both experimental $^{18}$ and clinical $^{19}$ situations, suggesting that reducing the amount of iron in the joint can be beneficial, although in the latter case undesirable side effects were observed, making chelation unsuitable for routine clinical purposes.

In vivo, iron is normally present intracellularly as haem, or stored as ferritin, while extracellular iron is bound by transferrin or lactoferrin. ${ }^{20}$ In these forms it is generally harmless, and in particular, transferrin or lactoferrin bound iron cannot catalyse the potentially damaging production of hydroxyl radicals from hydrogen peroxide and superoxide. ${ }^{21}$ However, in situations where iron levels exceed the binding capacity of these proteins, it may bind non-specifically to molecules such as citrate, or to other proteins. ${ }^{22}$ This fraction, referred to as "free" iron, can catalyse free radical production. The rheumatoid joint, where reactive oxygen species are produced by activated neutrophils or macrophages provides an enviroment in which the presence of "free" iron can lead directly to tissue destruction.

In this study it was found that about one third of the synovial fluids examined contained "free" iron, thus confirming earlier reports. ${ }^{15}$ It should be noted that such iron was only detectable when the assay was performed at $\mathrm{pH}$ 5.3, as at $\mathrm{pH} 7.4$ no "free" iron was detectable in any sample. However, the lower $\mathrm{pH}$ is comparable to that found in the microenvironment of an activated macrophage, where concentrations of hydrogen peroxide and superoxide are likely to be highest. At this $\mathrm{pH}$ transferrin is an ineffective iron binder, whereas lactoferrin remains effective. ${ }^{7}$ Lactoferrin is thus likely to be a key molecule in determining whether "free" iron is present in the synovium in vivo. Our results provide three pieces of evidence to support this hypothesis. Firstly, lactoferrin, but not transferrin concentrations were significantly lower in synovial fluids in which "free" iron was present than in those where it was not detected (fig 2). Secondly, addition of exogenous lactoferrin, but not transferrin, to synovial fluid reduced the "free" iron concentration. Thirdly, the fact that the transferrin: albumin ratio in synovial fluid is similar to that in serum, whereas the lactoferrin concentration is much high than in serum, suggests that transferrin enters the synovium simply as a result of transudation and is not related to the inflammatory process. This indicates that relative lactoferrin deficiency, in the context of exigent free iron levels, existed in vivo, which was correctable in vitro and rendered the presence of an alternate competetive inhibitor unlikely. Transferrin increased the "free" iron concentration in some cases. This may reflect movement of iron from other molecules, whose iron binding is not $\mathrm{pH}$ dependent, to transferrin, which then releases at least some of its iron at $\mathrm{pH} 5.3 .^{23}$

Lactoferrin in synovial fluid comes from degranulating neutrophils, where it is stored in secondary granules. ${ }^{24}$ Neutrophil lactoferrin is thought to function as an antimicrobial and anti-inflammatory agent as a result of its iron scavenging ability, ${ }^{25}$ but it is evident that the amount produced or released into the synovial fluid is not always sufficient to neutralise all the iron present. If lactoferrin concentrations in the synovium could be increased, synovial inflammation and tissue destruction might be reduced. This strategy would avoid the unwanted side effects that accompany use of chelating agents to lower synovial iron concentrations. ${ }^{18}$

One point needing clarification is the possible adverse role of autoantibodies to lactoferrin. Lactoferrin is one of the target antigens of antineutrophil cytoplasmic antibodies (ANCA) and these have been detected in a small proportion of synovial fluids from RA patients. ${ }^{26}$ It is possible that they could affect the ability of lactoferrin to bind synovial iron, as we have found that antilactoferrin IgG causes lactoferrin bound iron to become reactive in the bleomycin assay. ${ }^{27}$

As well as providing evidence for the importance of lactoferrin in controlling the appearance of "free" iron in the synovium, this work has also considered possible underlying mechanisms for the accumulation of iron in the synovium. Iron homeostasis is normally tightly controlled by the IRP/IRE system, the presence of excess iron causing conversion of IRPs to the non-RNA binding form, and consequently increasing the availability of ferritin for iron storage while reducing unwanted cellular iron uptake by down regulating transferrin receptor expression. ${ }^{34}$ It might therefore be expected that iron accumulation in the rheumatoid joint would trigger this protective mechanism. How- 
ever, $\mathrm{H}_{2} \mathrm{O}_{2}$ and $\mathrm{NO}$, both of which are produced by synovial inflammatory cells, ${ }^{28}$ can have an opposing effect as they can convert IRPs back to the RNA binding form. ${ }^{5}$ It was found that the proportion of active (that is, RNA binding) IRP in cells from synovial fluid showed no correlation with synovial fluid "free" iron concentrations, but did correlate with serum CRP, an established index of disease activity (fig 4 ). This strongly suggests that the effect of inflammatory mediators such as $\mathrm{H}_{2} \mathrm{O}_{2}$ and NO on IRP activity overrides that of iron itself. To our knowledge, this is the first time that the ability of inflammatory stimuli to override the effect of iron on IRP activity has been demonstrated in a clinical setting. This has important implications for the mechanism of local iron accumulation at inflammatory sites such as the rheumatoid joint and for the anaemia of chronic disease. It is also compatible with the suggestion ${ }^{29}$ that ferritin production may fail in synovial macrophages, as active IRP would prevent translation of ferritin mRNA.

Further confirmation that the inflammatory response affects IRP activation comes from the finding that the transcription factor $\mathrm{NF} \kappa \mathrm{B}$ was activated in synovial cells, and that this correlated with increased IRP activity. NFKB is activated by a variety of primary inflammatory mediators such as TNF $\alpha$, IL1, LPS, and thus has been implicated in the pathogenesis of RA. In particular, $\mathrm{H}_{2} \mathrm{O}_{2}$, a product of activated macrophages, can activate both IRP $^{5}$ and $\mathrm{NF \kappa B},{ }^{6}$ suggesting that it may play an important part in RA.

In conclusion, we have shown that lactoferrin probably fulfills a critical role in reducing the amount of potentially toxic "free" iron in the synovium, and that such iron may accumulate, at least in part, because inflammatory mediators $\left(\mathrm{H}_{2} \mathrm{O}_{2}, \mathrm{NO}\right)$ produced locally override the normal iron mediated homeostatic effect of IRP on iron uptake and storage. Lactoferrin is therefore an attractive potential candidate for gene therapy approaches to the treatment of RA.

The authors thank Dr K Chaudhuri for providing clinical data on patients in this study and Dr G J Feng for advice on NFKB on patients in this study and Dr G J Feng for advice on NFkB
assays. Supported by the McFeat Bequest and the Arthritis and Rheumatism Council.

1 Blake DR, Gallagher PJ, Potter AR, Bell MJ, Bacon PA. The Bake DR, Gallagher PJ, Potter AR, Bell MJ, Bacon PA. The effect of synovial iron on the progression
disease. Arthritis Rheum 1984;27:495-501.

2 Burkhardt $\mathrm{H}$, Schwingel M. Oxygen radicals as effectors of cartilage destruction. Arthritis Rheum 1986;29:379-87.

3 Melefors Ö, Hentze MW. Iron regulatory factor- the conductor of cellular iron regulation. Blood Rev 1993; 251-8

4 Klausner R, Rouault TA, Harford JB. Regulating the fate of mRNA: the control of cellular iron metabolism. Cell 1993 72:19-28.
5 Pantopoulos K, Weiss G, Hentze MW. Nitric oxide and oxidative stress $\left(\mathrm{H}_{2} \mathrm{O}_{2}\right)$ control mammalian iron metabolism

6 Baeuerle PA, Henkel T. Function and activation of NF-Kappa B in the immune system. Annu Rev Immunol 1994;12:141-79.

7 Aisen P, Leibman A. Lactoferrin and transferrin: a comparative study. Biochim Biophys Acta 1972;57:31423.

8 Etherington DJ, Pugh G, Silver IA. Collagen degradation in an experimental inflammatory lesion: studies on the role of the macrophage. Acta Biol Med Ger 1981;40:1625-31. 9 Arnett FC, Edworthy SM, Bloch DA, McShane DJ, Fries JF, Cooper NS, et al. The American Rheumatism Associa-
tion 1987 revised ARA criteria for classification of rheumatoid arthritis. Arthritis Rheum 1988;31:315-24.

10 Cassidy JT, Levinson JE, Bass JC, Baum J, Brewer EJ, Fink $\mathrm{CW}$, et al. A study of classification criteria for a diagnosis of juvenile rheumatoid arthritis. Arthritis Rheum 1986;29: 274-81.

11 Espinoza LR, Cuellar ML, Silveira LH. Psoriatic arthritis. Curr Opin Rheumatol 1992;4:470-8.

12 Gutteridge JMC, Rowley DA, Halliwell B. Superoxidedependent formation of hydroxyl radicals in the presence of dependent formation of hydroxyl radicals

13 Gray NK, Quick S, Goossen B, Constable A, Hirling H, Kühn LC, et al. Recombinant iron-regulatory factor functions as an iron-responsive-element-binding protein, a translational repressor and an aconitase. A functional assay for translational repression and direct demonstration of the iron swicth. Eur J Biochem 1993;218:657-67.

14 Hentze MW, Roualt TA, Harford JB, Klausner RD. Oxidation-reduction and the molecular mechanism of a regulatory RNA-protein interaction. Science 1989;244: regulatory.

15 Gutteridge JMC. Bleomycin-detectable iron in knee-joint synovial fluid from arthritic patients and its relationship to the extracellular antioxidant activities of caeruloplasmin, transferrin and lactoferrin. Biochem J 1987;245:415-21.

16 Evans PJ, Halliwell B. Measurement of iron and copper in biological systems: bleomycin and copper-phenanthroline assays. Meth Enzymol 1994;233:82-92.

17 Brock JH. Lactoferrin. In: Aggarwal BB, ed. Human cytokines. Malden, Massachussetts: Blackwell Science, 1998: 92-123.

18 Andrews FJ, Morris CJ, Kondratowicz G, Blake DR. Effect of iron chelators on inflammatory joint disease. Ann Rheum Dis $1987 ; 46: 327-33$

19 Blake DR, Winyard PG, Lunec J. Cerebral and ocular toxicity induced by desferrioxamine. Q J Med 1985;56:345-55.

20 Crichton RR, Ward RJ. Structure and molecular biology of iron binding proteins and the regulation of "free" iron pools. In: Lauffer RB, ed. Iron and human disease. Boca Raton, Florida: CRC Press, 1992: 23-75.

21 Halliwell B, Gutteridge JMC. Oxygen, free radicals and iron in relation to biology and medicine: some problems and concepts. Arch Biochem Biophys 1986;246:501-14.

22 Hershko C, Graham G, Bates GW, Rachmilewitz EA. Nonspecific serum iron in thalassaemia: an abnormal serum iron fraction of potential toxicity. Br J Haematol 1978;40: $255-63$.

23 Lestas $\mathrm{AN}$. The effect of $\mathrm{pH}$ upon human transferrin: selective labelling of the two iron-binding sites. Br J Haematol 1976;32:341-50.

24 Masson PL, Heremans JF, Schonne E. Lactoferrin, an ironbinding protein in neutrophilic leukocytes. J Exp Med 1969;130:643-58.

25 Sanchez L, Calvo M, Brock JH. Biological role of lactoferrin. Arch Dis Child 1992;67:657-61.

26 Afeltra A, Sebastiani GD, Galeazzi M, Caccavo D, Ferri GM, Marcolongo R, et al Antineutrophil cytoplasmic antibodies in synovial fluid and in serum of patients with rheumatoid arthritis and other types of synovitis. J Rheumatol 1996;23:10-15.

27 Brock JH, Lamont A, Boyle DJ, Holme ER, McSharry C, Bunn JEG, et al. Antibodies to lactoferrin - a possible link between cow's milk intolerance and autoimmune disease. Biochem Soc Trans 1997;25:317s.

28 McInnes IB, Leung BP, Field M, Wei XQ, Hueng FP, Sturrock RD, et al. Production of nitric oxide in the synovial membrane of rheumatoid and osteoarthritis patients. J Exp Med 1996;184:1519-24.

29 Trenam CW, Winyard PG, Morris CJ, Blake DR. Ironpromoted oxidative damage in rheumatic diseases. In: Lauffer RB, ed. Iron and human disease. Boca Raton, Florida: CRC Press, 1992: 395-417. 